\title{
Factor Extraction and Bicluster Analysis on Halal Destinations in Lombok Island
}

\author{
Desy Komalasari ${ }^{1}$, Mustika Hadijati ${ }^{2}$, Nurul Fitriyani ${ }^{3}$, Agus Kurnia ${ }^{4}$ \\ ${ }_{1}^{1}$ Mathematics, Universitas Mataram, Indonesia, e-mail : desykomalasari@unram.ac.id \\ 2 Mathematics, Universitas Mataram, Indonesia, e-mail : mustika.hadijati@unram.ac.id \\ 3 Mathematics, Universitas Mataram, Indonesia, e-mail : nurul.fitriyani@unram.ac.id \\ ${ }^{4}$ Mathematics, Universitas Mataram, Indonesia, e-mail : aguskurnia@unram.ac.id
}

\begin{tabular}{|c|}
\hline $\begin{array}{l}\text { Article History } \\
\text { Received : 03-06-2020 } \\
\text { Revised : 24-07-2020 } \\
\text { Accepted : 26-08-2020 }\end{array}$ \\
\hline $\begin{array}{l}\text { Keywords: } \\
\text { Bicluster Analysis; } \\
\text { Factor Analysis; } \\
\text { Halal Tourism; } \\
\text { Plaid Algorithm; } \\
\text { Tourism }\end{array}$ \\
\hline 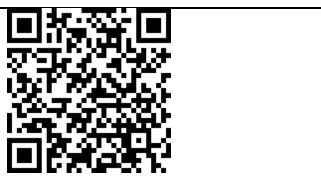 \\
\hline
\end{tabular}

\begin{abstract}
Indonesia is one of the countries currently developing the concept of halal tourism. Halal tourism includes many variables that are related to each other, which need to be grouped into several main factors that affect tourist visits. This study was conducted to group the variables associated with halal tourism visits to Lombok Island using factor analysis and to classify subdistricts and halal tourism destinations on Lombok Island using the Plaid Bicluster algorithm. Based on the analysis using the main component extraction technique in factor analysis with varimax rotation, it can be concluded that the 9 halal tourism characteristic variables can be grouped into 2 main factors. Furthermore, by using the Plaid Bicluster algorithm, 2 Bicluster were produced. There were 7 sub-districts and 9 destinations formed in Bicluster I, and 8 sub-districts and 3 destinations formed in Bicluster II.
\end{abstract}

ABSTRACT

This is an open access article under the CC BY-SA license.

DOI: https://doi.org/10.30812/varian.v4i1.743

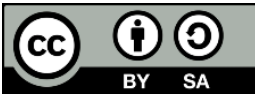

\section{A. INTRODUCTION}

Industry in the tourism sector is one aspect of economic development that can spur the development of regional economy and prosperous society. The tourism industry which is currently developing is the halal tourism industry, one of which is happening in Indonesia. Based on data obtained from the World Travel and Tourism Council, tourism can increase an area's income by 12\% (Zade, 2013).

Indonesia won an award at The 2015 World Travel Summit and Exhibition which was held in the United Arab Emirates. Indonesia won three awards, of which two were won by Lombok Island. Lombok, which is one of the islands in Indonesia, has been named the World's Best Halal Tourism Destination and Halal Honeymoon in the World Halal Travel Awards 2015 (Subarkah, Junita Budi Rachman, \& Akim, 2020) . A year later, Lombok was re-entered into 3 categories, namely the World's Best Halal Beach Resort, Halal Tourism Website, and Halal Honeymoon Destination. Lombok continues to improve itself in order to improve the concept of halal tourism in its area. The choice of Lombok in this event does not mean that Lombok can only be visited by Muslim tourists, but it is also open to other tourists with diverse origins. The typical halal tourism provided by Lombok Island is a sensation of local people's wisdom. Tourists are invited to be able to understand the values of Islamic sharia, and enjoy the beauty of religious tourism from the other side, surrounded by the beauty of charm in natural tourist destinations.

Based on the West Nusa Tenggara Province Regulation No. 2 Year 2016, halal tourism is an activity in the form of tourist visits, where product facilities, services, and tourism in destinations and tourism industry are 
managed by fulfilling the sharia concept. In this regulation, the intended halal tourism covers destinations, marketing and promotion, industry, institutions, guidance, supervision, and financing (Subarkah et al., 2020) and (Suyatman, Ruminda, \& Yatmikasari, 2018). Many variables support the concept of halal tourism, including the availability of public facilities that can support the convenience of tourist activities, such as the location and worship equipment for Muslim tourists, syaria-standard purification equipment, service and product sales industry by including the halal logo, the direction of Qibla in each room, information the location of the mosque, and so on. There are also other variables, such as local wisdom, natural attractions, cultural and artificial attractions, promotion of tourist attractions, and so on. The linkages between these variables need to be grouped into a number of main factors associated with tourist visits.

In multivariate statistics, one of the tools that are useful in grouping variables is factor analysis. This analysis is used with the aim of finding relationships between several variables, so that a new set of variables can be formed with a number that is less than the number of initial variables. A collection of correlated variables is called a factor, where all variables are relatively high correlated with each other in one factor, and relatively low correlated with other factors. Another popular analysis is cluster analysis, which classifies objects into relatively homogeneous clusters (Mattjik \& Sumertajaya, 2011). In contrast to cluster analysis, Bicluster analysis performs the classification of patterns simultaneously in the direction of rows and columns in the data matrix (Zhao, Liew, Wang, \& Yan, 2012).

Previous research has been conducted by (Komalasari, 2014) regarding the 2012 Visit Lombok Sumbawa tourism program using factor analysis and cluster centroids. Other studies have reviewed the factors that influence tourist satisfaction, and it is found that the cost factor greatly influences tourist satisfaction (Suanmali, 2014). Hierarchical cluster techniques have also been developed by estimating multiscale bootstrap resampling technique using average linkage (Isah, Abdullahi, \& Waziri, 2013). The segmentation of tourists using demographic and travel characteristics has also been studied, and it is found that the safety of the destination is one of the indicators that is closely related to tourist visits (Birdir, 2015).

The purpose of this study is to group variables related to halal tourism visits to Lombok Island using factor analysis techniques. In addition, a grouping of sub-districts and halal destinations in Lombok Island was carried out using Bicluster analysis. The results of this study are expected to be one of the supporting information for government programs in increasing halal tourism on Lombok Island.

\section{B. LITERATURE REVIEW}

\section{Factor Analysis}

Factor analysis is an analysis that can be used to examine patterns or relationships that underlie a large number of variables and to determine whether the information can be summarized in a series of factors or smaller components. Factor analysis is a technique of interdependence whose main purpose is to determine the underlying structure among the variables in the analysis. In general, factor analysis provides a tool for analyzing the structure of interrelationships (correlation) among a large number of variables by defining a set of highly interrelated variables, known as factors. These groups of variables (factors) are assumed to represent dimensions in the data (Hair Jr, Black, Babin, \& Anderson, 2010).

This analysis explains the relationship between $p$ variables, by raising $m$ important factors. In this case, the number of tripping factors is usually smaller than the number of original variables $(m<p)$. For example, $\mathbf{X}$ is a random vector on the $i$-th observation with $p$ components, with a mean vector $\boldsymbol{\mu}$ and a covariance variance matrix $\boldsymbol{\Sigma}$. Vector $\mathbf{X}$ is expressed as a linear combination of common factors $f_{1}, f_{2}, \cdots, f_{, m}$ and specific factors $\varepsilon_{1}, \varepsilon_{1}, \cdots, \varepsilon_{, p}$, as in Equation (1) (Lacobucci, 2001).

$x_{p}-\mu_{p}=l_{p 1} f_{1}+l_{p 2} f_{2}+\cdots+l_{p m} f_{, m}+\varepsilon_{p}$

Equation (1) is described in the following matrix notation.

$\mathbf{X}_{\mathrm{px} 1}-\boldsymbol{\mu}_{\mathrm{px} 1}=\mathbf{L}_{\mathrm{pxm}} \mathbf{F}_{\mathrm{mx} 1}+\boldsymbol{\varepsilon}_{\mathrm{px} 1}$ 


$$
\left[\begin{array}{c}
x_{1}-\mu_{1} \\
x_{2}-\mu_{2} \\
\vdots \\
x_{p}-\mu_{p}
\end{array}\right]=\left[\begin{array}{cccc}
l_{11} & l_{12} & \cdots & l_{1 m} \\
l_{21} & l_{22} & \cdots & l_{2 m} \\
\vdots & \vdots & \ddots & \vdots \\
l_{p 1} & l_{p 2} & \cdots & l_{p m}
\end{array}\right]\left[\begin{array}{c}
f_{1} \\
f_{2} \\
\vdots \\
f_{m}
\end{array}\right]+\left[\begin{array}{c}
\varepsilon_{1} \\
\varepsilon_{2} \\
\vdots \\
\varepsilon_{p}
\end{array}\right]
$$

where $x_{i}$ represents the $i-t h$ random variable; $\mu_{i}$ represents the average of $i$-th variable; coefficient $l_{i j}$ is loading of the $i$-th random variable on the $j$-th factor; $f_{j}$ represents the $j$-th joint factor; $\varepsilon_{i}$ represents the $i$-th specific factor; $\mathbf{L}$ represents the matrix of factor loadings; $i=1,2, \cdots, p$ and $j=1,2, \cdots, m$.

The core technique in conducting factor analysis is factor extraction, which is a method for reducing the dimensions of the data in order to obtain factors with a smaller amount, which can explain the relationship between the factors studied. One of the factor extraction techniques commonly used is the principal component analysis. Each major component in $\Sigma$ has eigenvalues and eigenvectors $\left(\hat{\lambda}_{1}, \hat{e}_{1}\right),\left(\hat{\lambda}_{2}, \hat{e}_{2}\right), \cdots,\left(\hat{\lambda}_{p}, \hat{e}_{p}\right)$, where the first eigenvalue is always greater than the second eigenvalue, so the second eigenvalue will be greater from the third eigenvalue, and so on $\lambda_{1} \geq \lambda_{1} \geq \cdots \geq \lambda_{p}>0$. The variance-covariance matrix in the principal component analysis is $\Sigma=L L^{\prime}$ when the specific variance is $\operatorname{cov}(\varepsilon)=0$ (Johnson \& Wichern, 2002). The grouping of factors that represent variables is based on the magnitude of the eigenvalues and the percentage of the total variance. In this case, factors with eigenvalues higher than the average eigenvalue are considered significant and included in the model, with other factors excluded (Costello \& Osborne, 2005).

\section{Bicluster Analysis}

Cluster analysis is used in classifying objects into relatively homogeneous clusters. Objects in each cluster tend to be similar, but tend to be different from objects in other clusters. Determination of object similarity is done using a distance matrix (proximity matrix), which is a square matrix and symmetry with the same number of objects in rows and columns (Mattjik \& Sumertajaya, 2011). In contrast to traditional cluster procedures that look for groups of coherent patterns using a whole set of features, Bicluster analysis is useful for finding local coherent patterns hidden in a data matrix. This analysis classifies patterns simultaneously in row and column directions in the data matrix (Zhao et al., 2012).

The Bicluster principle is to divide the data matrix into sub matrices and use variance to evaluate the quality of each Bicluster. Plaid algorithm is an algorithm that is presented in object data and matrix variables. In the plaid algorithm model, visualization of objects and variables can be formed on a Bicluster or not. Often the data used is in the form of a matrix containing the correlation between each row representing the object and each column representing the variable. The plaid model is often used as follows is an equation (3):

$$
y_{i j}=\mu_{0}+\sum_{k=1}^{K} \mu_{k} \rho_{i k} K_{j k}
$$

$y_{i j}$ is the data matrix, where $i=1,2, \cdots, n$ and $j=1,2, \cdots, p$. The $i$-th row index represents the object and the $j-t$ th column index represents the variable. Next, the strength measurement between the $i-t h$ object which is correlated with the $j-t h$ variable is represented by $y_{i j}$. The coefficient $\mu_{0}$ is the general matrix of the background color of the heat map, while $\mu_{k}$ representing the color (characteristics) added in the $k$-th Bicluster (Lazzeroni \& Owen, 2002). 


\section{RESEARCH METHOD}

Preliminary data were obtained from the West Nusa Tenggara Provincial Tourism Office. Furthermore, primary data were obtained by distributing questionnaires to 100 tourists visiting several destinations on the Lombok Island. Sampling of tourists and destinations was done using simple random sampling techniques. The research variables used include 9 variables which are described in Table 1. In addition, the data of tourist objects or destinations that are spread on Lombok Island were also used along with the distance of each location.

Table 1. Research Variables

\begin{tabular}{cl}
\hline Variables & Argument \\
\hline $\mathbf{X}_{\mathbf{1}}$ & $\begin{array}{l}\text { Promotion } \\
\text { The availability of online information about halal destinations on social } \\
\text { media, as well as billboards in places that are frequently visited }\end{array}$ \\
\hline $\mathbf{X}_{\mathbf{2}}$ & $\begin{array}{l}\text { Halal tourism objects and attractions } \\
\text { Halal tourism objects and attractions on Lombok Island are very interesting }\end{array}$ \\
\hline $\mathbf{X}_{\mathbf{3}}$ & $\begin{array}{l}\text { Security } \\
\text { The condition of the tourist destinations is quite safe }\end{array}$ \\
\hline $\mathbf{X}_{\mathbf{4}}$ & $\begin{array}{l}\text { Facilities around halal destinations } \\
\text { The availability of worship places, worship equipment, and toilets }\end{array}$ \\
\hline $\mathbf{X}_{\mathbf{5}}$ & $\begin{array}{l}\text { Cleanliness } \\
\text { The condition of the tourist area is very clean }\end{array}$ \\
\hline $\mathbf{X}_{\mathbf{6}}$ & $\begin{array}{l}\text { Culinary } \\
\text { Food and drinks are available at the location of halal destinations }\end{array}$ \\
\hline $\mathbf{X}_{\mathbf{7}}$ & Facilities and infrastructure \\
& The access road to tourist destinations is easy to reach \\
\hline $\mathbf{X}_{\mathbf{8}}$ & $\begin{array}{l}\text { Cultures and customs } \\
\text { Cultures and customs of halal destinations offered are attractive }\end{array}$ \\
\hline $\mathbf{X}_{\mathbf{9}}$ & $\begin{array}{l}\text { Strategic } \\
\text { The destination location is very strategic and easy to reach }\end{array}$ \\
\hline
\end{tabular}

Furthermore, the research steps carried out are as follows.

1. Data preparation and collection. Secondary data regarding halal tourism obtained through relevant agencies, and primary data obtained through questionnaires and interviews.

2. Testing the validity of the instrument using the Pearson correlation coefficient and testing the reliability of the instrument using the Cronbach Alpha coefficient.

3. Factor analysis, begins with testing the assumptions of the data by taking into account the measure of Kaiser-Mayer-Olkin Measure of Sampling Adequacy (KMO MSA) and Anti-Image Matrix, and using the Bartlett's sphericity test. After the assumptions are fulfilled, a factoring process is carried out, with stages such as determining the variance-covariant matrix, eigenvalues and eigenvectors, loading weights, and rotating factors. Moreover, testing the accuracy of the factors formed and interpreting the grouping of factors formed.

4. Data grouping based on secondary data in the form of the distance between sub-districts and halal destinations on Lombok Island using the plaid Bicluster algorithm.

5. Drawing conclusions.

\section{RESULTS AND DISCUSSION}

The instrument results of the questionnaire were first tested by validity and reliability tests. These tests were carried out to detect the extent of the instruments or measuring instruments used on the target. These tests need to be done on the data, so that the results from the instrument are not much different from the actual situation. A study is said to have valid results if there are similarities between the data obtained and the actual data state on the object. The validity test of the instruments was carried out using the Pearson correlation coefficient. The test carried out produce a significant correlation coefficient with a $5 \%$ 
significance level, so it can be concluded that all items on the instrument can be said to be valid. Moreover, reliability test of the instruments was carried out using the Cronbach Alpha coefficient, with a minimum internal consistency coefficient of 0.60 (Taherdoost, 2016). Test conducted produce a coefficient value of 0.842 , so it can be concluded that the instruments used were reliable.

Furthermore, the 9 variables related to halal tourism visits to Lombok Island were grouped using factor analysis with varimax rotation, followed by data grouping based on the distance between sub-districts and halal destinations on Lombok Island using the plaid Bicluster algorithm.

\section{Factor Analysis}

Before conducting the analysis, it is necessary to ensure that the data matrix has sufficient correlation to justify the application of factor analysis. To ensure this, it can be done by taking into account the measure of the Kaiser-Meyer-Olkin Measure of Sampling Adequacy (KMO MSA) to measure the relationship between variables. This measure was calculated for the entire correlation matrix and each individual variable. KMO $M S A$ for all matrices or individual variables with values more than 0.5 indicate compatibility. Based on the analysis results, $K M O M S A>0,851$ were obtained. Therefore, it can be concluded that the sample used was appropriate and adequate. Another method for determining the suitability of factor analysis is to test the overall significance of all correlations in the correlation matrix using the Bartlett's sphericity test. This test shows statistical significance regarding correlations between variables (Hair Jr et al., 2010). Based on the analysis results, obtained a value of 317.8 which was significant at the $5 \%$ significance level. So, it can be concluded that there was a significant correlation between variables and the sample was sufficient to be analyzed by factor analysis.

The next step is to determine an anti-image correlation matrix that shows the negative value of the partial correlation. This matrix represents a partial correlation matrix between variables and represents the extent to which the factors explain one another. The values on the diagonal matrix show the MSA value for each variable, and the other values show a partial correlation between variables. Factor analysis can be run if the value $M S A>0,5$, but if there are variables with values $M S A<0,5$, then these variables must be excluded one by one. Partial or anti-image correlations greater than 0.7 indicate a data matrix which is not suitable for factor analysis (Hair Jr et al., 2010). Based on the results, it was obtained that each individual variable meets an MSA value over 0.5 and a partial correlation less than 0.7 .

Furthermore, the dimensions of the data were reduced by factor extraction, so factors with a smaller number of variables was produced, which can explain the correlation or relationship between factors. In this study, extraction techniques were used with the principal component method. Grouping the number of factors that represent variables was done based on the amount of eigenvalues and the percentage of the total variance. Factors with eigenvalues greater than the mean eigenvalues were considered significant and included in the factor analysis, while others were excluded. Eigenvalues can show the importance of each factor relatively in producing variance values. The arrangement of eigenvalues is sorted from largest to smallest, where eigenvalues less than 1 were not considered in the calculation of the number of factors for the variance-covariance matrix.

The analysis conducted shows that there were only 2 components that have eigenvalue with value of more than 1, with eigenvalues for component I and component II were 4.066 and 1.070, respectively. Moreover, based on (Hair Jr et al., 2010), analyzes with a total variance value of $60 \%$ (and in some cases even less) are considered satisfactory. The analysis shows that the total variance value that can be explained was $57,059 \%$, so it can be concluded that the 9 characteristic variables of tourist visits to halal destinations can be grouped into 2 main components.

The extraction stage was continued with factor rotation. The results of the extraction process (unrotated factor loadings) show the correlation between factors and variables, with the matrix component of the factors as shown in Table 2. However, the factor matrix resulting from the extraction process listed in Table 2 (unrotated factor loadings) is still difficult to interpret. Therefore, factor rotation is needed so as to sharpen the differences in the factor loadings formed by each variable, and maintain a state where there is no correlation between factors. In this study, orthogonal rotation was used by the varimax method, with the 
aim of reducing the number of initial variables by minimizing variables with values of low factor loadings and high factor loadings in a general factor. The unrotated and rotated factor loadings are shown in Table 2.

Table 2. Comparison between Rotated and Unrotated Factor Loadings

\begin{tabular}{ccccc}
\hline \multirow{2}{*}{ Variables } & \multicolumn{4}{c}{ Factor Loadings } \\
\cline { 2 - 5 } & \multicolumn{2}{c}{ Unrotated } & \multicolumn{2}{c}{ Rotated } \\
\cline { 2 - 5 } & I & II & I & II \\
\hline $\mathrm{X}_{1}$ & 0.669 & -0.103 & 0.602 & 0.311 \\
\hline $\mathrm{X}_{2}$ & 0.643 & 0.014 & 0.511 & 0.389 \\
\hline $\mathrm{X}_{3}$ & 0.733 & -0.263 & 0.747 & 0.218 \\
\hline $\mathrm{X}_{4}$ & 0.547 & 0.346 & 0.239 & 0.601 \\
\hline $\mathrm{X}_{5}$ & 0.609 & -0.504 & 0.789 & -0.050 \\
\hline $\mathrm{X}_{6}$ & 0.556 & 0.437 & 0.193 & 0.680 \\
\hline $\mathrm{X}_{7}$ & 0.845 & 0.016 & 0.674 & 0.510 \\
\hline $\mathrm{X}_{8}$ & 0.532 & 0.602 & 0.076 & 0.800 \\
\hline $\mathrm{X}_{9}$ & 0.832 & -0.249 & 0.819 & 0.287 \\
\hline & & & &
\end{tabular}

Table 2 shows the process results after factor extraction. The rotated factor loadings data shows a clearer and more real distribution of the variables. The grouping of each variable in component I or component II depends on the value of the resulting factor loadings. For example, the variable $X_{1}$ (Promotion) will be included in Factor I because the factor loading value or the correlation value of variable $X_{1}$ with Factor I (that is 0.602), is higher than the correlation value between $X_{1}$ and Factor II (that is 0.311 ). Therefore, the variable $X_{1}$ is grouped into Factor I. The same thing applies to other variables, so the components in Factor I, including $X_{1}$ (Promotion), $X_{2}$ (Halal tourism objects and attractions), $X_{3}$ (Security), $X_{5}$ (Cleanliness), $X_{7}$ (Facilities and Infrastructure), and $X_{9}$ (Strategic), while Factor II, includes $X_{4}$ (Facilities around halal destinations), $X_{6}$ (Culinary), and $X_{8}$ (Cultures and customs).

\section{Bicluster Analysis}

In Bicluster analysis, the distance between sub-districts and halal destinations in Lombok Island were used. Data containing the distance between each sub-district and each halal tourism object listed is given in Table 3. The grouping of sub-districts and halal destinations using Bicluster analysis on data can be presented in the form of a matrix with dimensions of $9 \times 12$, with 9 rows representing 9 sub-districts, namely Ampenan, Selaparang, Mataram, Selong, Pujut, Suela, West Praya (Praya Barat), Batulayar, and Bayan. Moreover, 12 columns represent halal destinations, namely the West Nusa Tenggara Provincial State Museum (Museum Negeri) in Ampenan Sub-District, the Islamic Center of West Nusa Tenggara Province in Selaparang Sub-District, The Old Town of Ampenan (Kota Tua Ampenan) in Ampenan Sub-District, Tomb of Loang Baloq (Makam Loang Baloq) in Mataram Sub-District, Al-Mujahidin Mosque (Masjid Al-Mujahidin) in Selong Sub-District, Sade Village (Desa Sade) in Pujut Sub-District, Tomb of Selaparang (Makam Selaparang) in Suela Sub-District, Tomb of Batulayar (Makam Batulayar) in Batulayar Sub-District, Tomb of Wali Nyatoq (Makam Wali Nyatoq) in Pujut Sub-District, Setanggor Village (Desa Stanggor) in West Praya Sub-District, Ancient Mosque of Gunung Pujut (Masjid Kuno Gunung Pujut) in Pujut Sub-District, and Ancient Mosque of Bayan (Masjid Kuno Bayan) in Bayan Sub-District. 
Table 3. Distance between Sub-Districts and Halal Tourism Objects

\section{Tourism Objects}

\begin{tabular}{|c|c|c|c|c|c|c|c|c|c|c|c|c|}
\hline Sub-Districts & 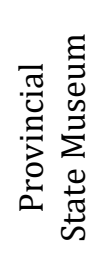 & 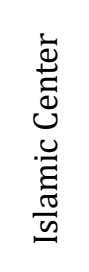 & 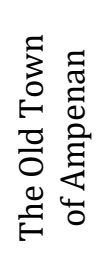 & 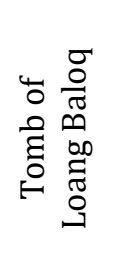 & 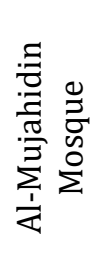 & 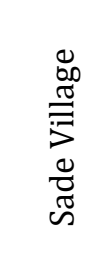 & 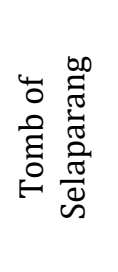 & 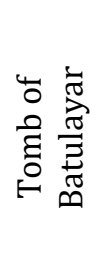 & 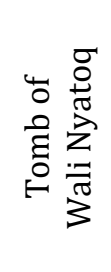 & 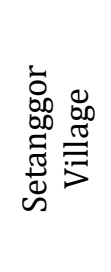 & 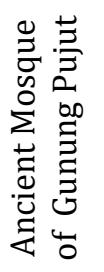 & 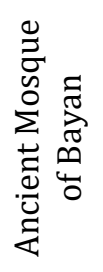 \\
\hline Ampenan & 0.8 & 2.4 & 1.8 & 3.2 & 54.8 & 42.5 & 67.4 & 8.0 & 43.6 & 32.5 & 39.4 & 79.2 \\
\hline Selaparang & 5.8 & 3.7 & 5.4 & 8.5 & 52.5 & 41.2 & 65.1 & 10.1 & 42.2 & 31.4 & 38.1 & 76.6 \\
\hline Mataram & 3.4 & 2.9 & 5.7 & 4.7 & 51.3 & 38.6 & 64.0 & 11.9 & 39.7 & 28.6 & 35.5 & 79.9 \\
\hline Selong & 53.8 & 52.1 & 55.6 & 55.2 & 1.0 & 42.0 & 22.4 & 61.7 & 41.2 & 45.3 & 38.7 & 66.6 \\
\hline Pujut & 37.3 & 36.7 & 39.6 & 36.5 & 38.1 & 4.7 & 54.3 & 46.0 & 5.7 & 12.6 & 1.6 & 97.4 \\
\hline Suela & 63.2 & 61.5 & 65.0 & 64.7 & 22.0 & 57.0 & 4.1 & 71.2 & 56.2 & 57.5 & 53.8 & 48.4 \\
\hline West Praya & 28.6 & 28.0 & 30.9 & 27.8 & 41.6 & 13.8 & 54.9 & 37.1 & 14.8 & 4.6 & 10.7 & 98.0 \\
\hline Batulayar & 8.0 & 9.3 & 6.5 & 9.7 & 61.7 & 49.9 & 74.4 & 2.4 & 51.0 & 39.7 & 46.8 & 71.2 \\
\hline Bayan & 75.9 & 74.5 & 74.8 & 77.9 & 68.2 & 103.0 & 53.6 & 67.4 & 102.0 & 104.0 & 100.0 & 4.9 \\
\hline
\end{tabular}

Matrix $\mathbf{M}$ for Bicluster analysis was obtained based on Table 3, by including all corresponding row and column elements as matrix elements. Based on the analysis, 2 layers were obtained which showed that 2 Bicluster with different dimensions formed in the data. These dimensions were defined as the size of the Bicluster from which it was formed, which were then represented in the form of sub matrices. Bicluster I has dimension of $7 \times 9$ and Bicluster II has dimension of $8 \times 3$. The detailed analysis results of each Bicluster were visually shown in the form of a heat map. Heat map is a graphical representation of data, where each value contained in the data matrix is represented as a color. Heat map is used to simplify the process of interpreting the results of Bicluster, which contains correlations of data simultaneously between objects in rows and variables in columns. Different colors in the heat map represent the value of data correlation and represent whether the correlation of a data is classified as high or low.

Based on the analysis conducted, a sub matrix $\mathbf{M}_{\mathrm{BCI}}$ with dimension of $7 \times 9$ can be formed for Bicluster I analysis, that contains distances between each sub-district and each halal destination obtained for Bicluster I.

$\mathbf{M}_{\mathbf{B C I}}=\left(\begin{array}{ccccccccc}75.9 & 74.5 & 74.8 & 77.9 & 103 & 67.4 & 102 & 104 & 100 \\ 8.0 & 9.3 & 6.5 & 9.7 & 49.9 & 2.4 & 51.0 & 39.7 & 46.8 \\ 63.2 & 61.5 & 65.0 & 64.7 & 57.0 & 71.2 & 56.2 & 57.5 & 53.8 \\ 53.8 & 52.1 & 55.6 & 55.2 & 42.0 & 61.7 & 41.2 & 45.3 & 38.7 \\ 3.4 & 2.9 & 5.7 & 4.7 & 38.6 & 11.9 & 39.7 & 28.6 & 35.5 \\ 5.8 & 3.7 & 5.4 & 8.5 & 41.2 & 10.1 & 42.2 & 31.4 & 38.1 \\ 0.8 & 2.4 & 1.8 & 3.2 & 42.5 & 8.0 & 43.6 & 32.5 & 39.4\end{array}\right)$

In visual form, the $\mathbf{M}_{\mathbf{B C I}}$ sub matrix for Bicluster I analysis was interpreted using a heat map, shows in Figure 1(a). The heat map in Figure 1(a) provides information that there are 7 sub-districts and 9 destinations that were formed in Bicluster I, namely Ampenan, Selaparang, Mataram, Selong, Suela, Batulayar, and Bayan Sub-Districts, with destinations, namely the West Nusa Tenggara Provincial State Museum, Islamic Center of West Nusa Tenggara Province, The Old City of Ampenan, Tomb of Loang Baloq, Sade Village, Tomb of Batulayar, Tomb of Wali Nyatoq, Setanggor Village, and Ancient Mosque of Gunung Pujut, respectively from left to right.

Furthermore, based on the analysis that has been done, in addition to the formation of Bicluster I, Bicluster II was also formed with dimension of $8 \times 3$. The following sub matrix $\mathbf{M}_{\mathbf{B C I I}}$ contains distances between each sub-district and each destinations obtained for Bicluster II. 


$$
\mathbf{M}_{\text {BCII }}=\left(\begin{array}{ccc}
61.7 & 74.4 & 71.2 \\
41.6 & 54.9 & 98.0 \\
22.0 & 4.1 & 48.4 \\
38.1 & 54.3 & 97.4 \\
1.0 & 22.4 & 66.6 \\
51.3 & 64.0 & 79.9 \\
52.5 & 65.1 & 76.6 \\
54.8 & 67.4 & 79.2
\end{array}\right)
$$

In visual form, the $\mathbf{M}_{\mathbf{B C I I}}$ sub matrix for Bicluster II analysis was interpreted in the form of a heat map. The heat map in Figure 1(b) shows information that there are 8 sub-districts and 3 destinations that were formed in Bicluster II, namely Ampenan, Selaparang, Mataram, Selong, Pujut, Suela, West Praya, and Batulayar Sub-Districts, with destinations, namely Al-Mujahidin Mosque, Tomb of Selaparang, and Ancient Mosque of Bayan, respectively from left to right.

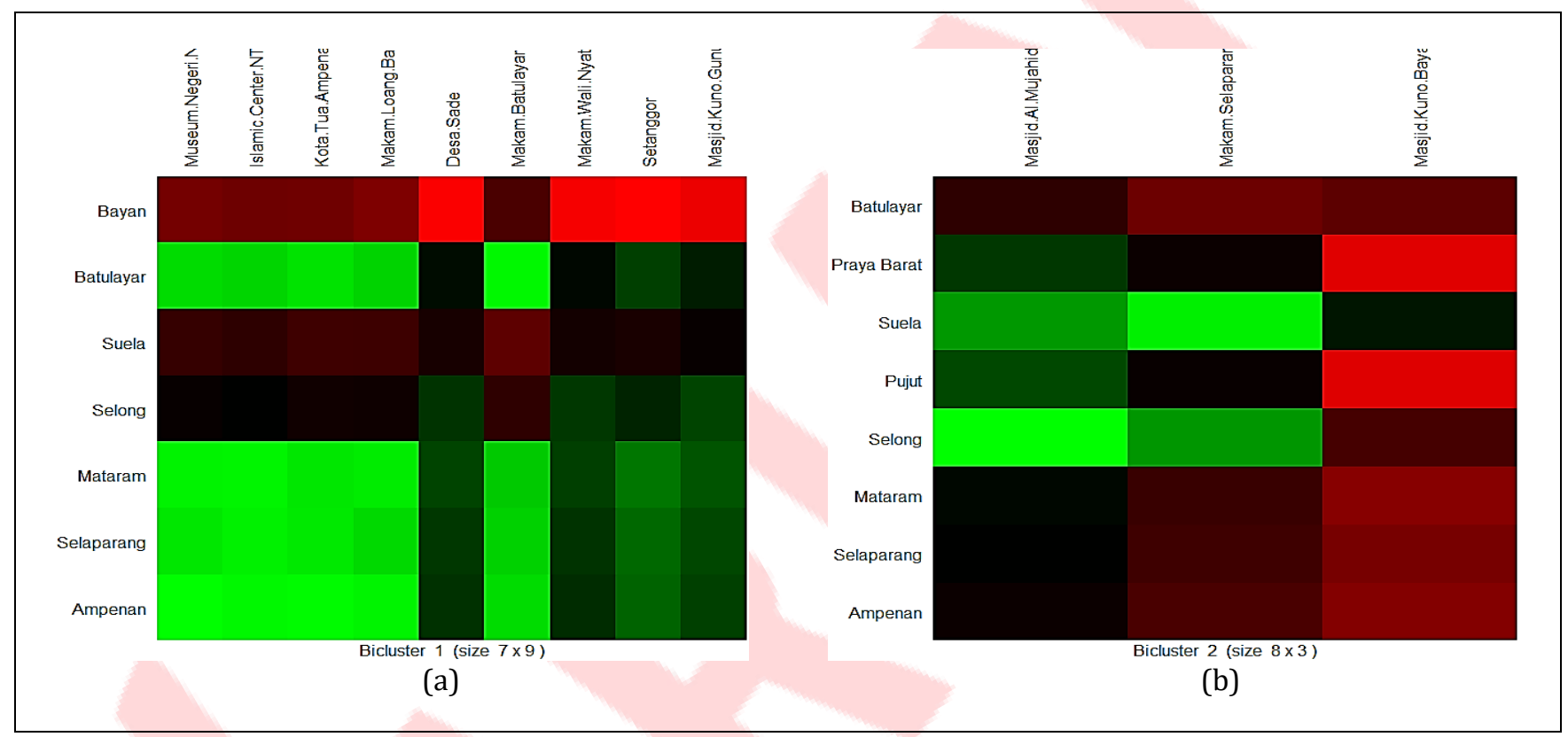

Figure 1. Visualization of Bicluster I and Bicluster II

The brighter (lighter) green color in the heat map produced, shows the higher correlation between objects and variables of a Bicluster. Conversely, the darker green color in the heat map produced, shows the lower correlation between objects and variables of a Bicluster. Furthermore, the brighter (lighter) red color on the heat map, showing the lower correlation between objects and variables of a Bicluster. Conversely, the darker red color in the heat map produced, indicating a higher correlation between objects and variables of a Bicluster, but lower when compared to a dark green color.

Other results obtained based on the analysis of Bicluster I and Bicluster II were bright (light) green showing a very high correlation from Bicluster elements, where dark (concentrated) parts indicate a relatively high correlation. Conversely, bright (light) red indicates a very low correlation from Bicluster elements, where the dark (concentrated) part indicates a relatively low correlation, which is certainly lower when compared to the correlation of dark (concentrated) green Bicluster elements.

For example, further information based on the $\mathbf{M}_{\mathbf{B C I}}$ sub matrix and the Bicluster I heat map in Figure 1(a), results in a bright (light) green color showing several sub-districts, namely Batulayar, Mataram, Selaparang, and Ampenan Sub-Districts classified as very highly correlated with tourism objects (destinations), namely West Nusa Tenggara Provincial State Museum, Islamic Center of West Nusa Tenggara, The Old Town of Ampenan, Tomb of Loang Baloq, and Tomb of Batulayar, with a very close distance, which is less than 20 kilometers. Another example based on the $\mathbf{M}_{\mathbf{B C I}}$ sub matrix and the Bicluster II heat map in Figure 1(b), 
indicates that the dark red color shows that the Ampenan, Selaparang, Mataram and Batulayar Sub-Districts were classified as having a low correlation with tourism objects (destinations), namely the Tomb of Selaparang and the Ancient Mosque of Bayan, with a relatively long distance, which is between 60-85 kilometers.

\section{E. CONCLUSION AND SUGGESTION}

The results of the factor analysis show that 9 characteristic variables related to tourist visits to halal destinations were grouped into 2 main components, namely Factor I and Factor II. Furthermore, Bicluster analysis for grouping sub-districts and halal destinations with $9 \times 12$ dimensions of data matrix formed 2 different dimensions Bicluster on data. Bicluster I formed a matrix data with $7 \times 9$ dimensions and Bicluster II formed a matrix data with $8 \times 3$ dimensions. By observing the distance between sub-districts and halal destinations, it appears that the closer the distance, the higher the correlation, and vice versa.

\section{ACKNOWLEDGEMENTS}

Researchers would like to thank the University of Mataram (UNRAM) for giving permission to collaborate in the field of research and provide moral support. Likewise with the NTB Tourism Office which has provided data support, so that this research can be carried out well.

\section{REFERENCES}

Birdir, S. S. (2015). Segmentation of Tourist Using Demographic and Travel Characteristics: The Case of Istanbul. International Review of Management and Marketing, 5(4), 221-229.

Costello, A. B., \& Osborne, J. (2005). Best Practices in Exploratory Factor Analysis: Four Recommendations for Getting the Most from Your Analysis. Practical Assessment Research \& Evaluation, 10(7), 1-9.

Hair Jr, J. F., Black, W. C., Babin, B. J., \& Anderson, R. E. (2010). Multivariate Data Analysis Seventh Edition. New Jersey: Pearson Prentice Hall.

Isah, A., Abdullahi, U., \& Waziri, V. O. (2013). A Hierarchical Cluster Analysis and Simulation of State Capitals in Nigeria for Tourism Exploration. International Journal of Latest Research in Science and Technology, 2(1), 437-441.

Johnson, R. A., \& Wichern, D. W. (2002). Applied Multivariat Statistical Analysis, Fifth Edition. Prentice Hall Inc., New Jersey.

Komalasari, D. (2014). Analisis Faktor Quartimax dan Cluster Hirarki Centroid pada Program Visit Lombok Sumbawa (VLS). Jurnal Penelitian Unram, 18(2), 89-98.

Lacobucci, D. (2001). Factor Analysis. Journal of Consumer Psychology's Special Issue on Methodological and Statistical Concerns of the Experimental Behavioral Researcher, 10(1-2), 75-82.

Lazzeroni, L., \& Owen, A. (2002). Plaid Models for Gene Expression Data. Statistica Sinica, 12, 61-86.

Mattjik, A. A., \& Sumertajaya, I. M. (2011). Sidik Peubah Ganda dengan Menggunakan SAS. Bogor: Institut Pertanian Bogor Press, Bogor.

Suanmali, S. (2014). Factors Affecting Tourist Satisfaction: An Empirical Study in the Northern Part of Thailand. SHS Web of Conferences, 12, 01027.

Subarkah, A. R., Junita Budi Rachman, \& Akim. (2020). Destination Branding Indonesia Sebagai Destinasi Wisata Halal. Jurnal Kepariwisataan: Destinasi, Hospitalitas Dan Perjalanan, 4(2), 84-97.

Suyatman, U., Ruminda, \& Yatmikasari, I. (2018). Pulau Lombok: Pengembangan Wisata Halal dalam Bingkai Kearifan Lokal. Pusat penelitian dan Penerbitan UIN SGD Bandung.

Taherdoost, H. (2016). Validity and Reliability of the Research Instrument: How to Test the Validation of a Questionnaire/ Survey in a Research. International Journal of Academic Research in Management, 5(3), 28-36.

Zade, A. A. E. (2013). Factor Analysis of Rural Tourism Development from Villagers Viewpoint in Chaharmahalva Bakhtiari Province. International Journal of Agriculture and Crop Sciences, 5(21), 2630-2633.

Zhao, H., Liew, A. W.-C., Wang, D. Z., \& Yan, H. (2012). Biclustering Analysis for Pattern Discovery: Current Techniques, Comparative Studies and Applications. Current Bioinformatics, 7, 43-55. 
10 | Jurnal Varian| Vol. 4, No. 1, Oktober 2020, Hal. 1-10 